\title{
Prevalence and risk factors for premalignant lesions in patients younger than 55 years old founded on colonoscopy on a tertiary center
}

\author{
Prevalencia y factores de riesgo para lesiones premalignas en pacientes menores de 55 \\ años sometidos a colonoscopia en un hospital de tercer nivel
}

\begin{abstract}
Maricela Jiménez-López ${ }^{*}$, César A. García-Romero², Moisés F. Rojas-Illanes² and José L. Martínez-Ordaz ${ }^{1}$ Gastric Surgery Department; ${ }^{2}$ Department of Colon and Rectum Surgery. Specialty Hospital, Centro Médico Nacional Siglo XXI, Instituto Mexicano del Seguro Social, Mexico City, Mexico
\end{abstract}

\begin{abstract}
Background: Colorectal cancer is an important cause of mortality, colonoscopy is effective to reduce its incidence and improve survival with the resection of premalignant lesions. Objective: To determine the prevalence, characteristics and histology of lesions in patients younger than 55 years of age in a tertiary hospital. Method: This is a retrospective observational study, we colected data at the Hospital de Especialidades del Centro Médico Nacional Siglo XXI, Instituto Mexicano del Seguro Social, with the report of 555 colonoscopies, and clinical data from the hospital archives of medic histories of selected patients. Results: Premalignant lesions were found on $40 \%$ of the patients. The findings were polyps in 98 cases with a size of $5.2 \mathrm{~mm}$; $54 \%$ were located in the colon, $24 \%$ in the sigmoid, $27 \%$ in the rectum and $1 \%$ in the anus. A prevalence of $63 \%$ of neoplastic polyps was observed (RR: 2.3; 95\% Cl: 1.5-3.7) in smokers; and 42\% (RR: 1.8; 95\% Cl: 1.2-2.6) in patients with alcohol consumption. Conclusions: The prevalence for premalignant lesions is similar for patients under 55 years of age. This highlights the importance of early diagnosis and avoiding progression. It would be convenient to extend the follow-up to second-level hospitals in patients with risk factors to contribute to improvement of public health system outcomes.
\end{abstract}

KEY WORDS: Colorectal cancer. Polyps. Premalignant lesions. Colonoscopy. Adenomas.

\section{Resumen}

Antecedentes: El cáncer colorrectal es causa importante de mortalidad y la colonoscopia es efectiva para reducir su incidencia y mejorar la supervivencia con la resección de las lesiones precursoras. Objetivo: Determinar la prevalencia, las características y la histología de las lesiones en pacientes < 55 años en un hospital de tercer nivel. Método: Se realizó un studio retrospectivo y observacional de enero de 2010 a diciembre de 2014 en el Hospital de Especialidades del Centro Médico Nacional Siglo XXI, Instituto Mexicano del Seguro Social, con el reporte de 555 colonoscopias y los datos clínicos de las historias hospitalarias de los pacientes incluidos en el estudio. Resultados: Los hallazgos fueron lesiones premalignas en el $40 \%$ de los pacientes, con pólipos en 98 casos y con un tamaño de $5.2 \mathrm{~mm}$; de ellos, el $54 \%$ se localizaron en el colon, el $24 \%$ en el sigmoides, el $27 \%$ en el recto y el 1\% en el ano. En los reportes se observó una prevalencia del $63 \%$ de pólipos neoplásicos (riesgo relativo [RR]: 2.3; intervalo de confianza del 95\% [IC 95\%]: 1.5-3.7) en pacientes con antecedente de tabaquismo, y del 42\% (RR: 1.8; IC 95\%: 1.2-2.6) con antecedente de consumo de alcohol. Conclusiones: La prevalencia

\footnotetext{
Correspondence:

*Maricela Jiménez-López

Av. José Ma. Vértiz, 1027

Col. Vértiz-Narvarte, Del. Benito Juárez

C.P. 03600, Ciudad de México, México

E-mail: maricela.jimenezmd@gmail.com
}

Date of reception: 08-02-2018

Cir Cir. 2018;86:188-192

Date of acceptance: 20-04-2018

DOI: 10.24875/CIRUE.M18000033
Contents available at PubMed www.cirugiaycirujanos.com 
de lesiones premalignas es similar para los menores de 55 años. Esto indica la importancia del diagnóstico oportuno y de evitar la progresión. Sería conveniente extender el seguimiento a hospitales de segundo nivel en pacientes con factores de riesgo para ampliar lo reportado y contribuir a mejorar los resultados en la sanidad pública.

PALABRAS CLAVE: Cáncer colorrectal. Pólipos. Lesiones premalignas. Colonoscopia. Adenoma.

\section{Background}

Colorectal cancer is a major cause of morbidity and mortality in the Western world. Endoscopic screening is effective to reduce the incidence and mortality of this condition'. Most patients who are diagnosed with colorectal neoplasms are older than 55 years, and colonoscopy in asymptomatic patients is considered a tool for timely detection, which is correlated with higher survival².

Risk factors for colorectal cancer include age ${ }^{3}$, male gender, alcohol consumption, smoking ${ }^{4}$, obesity, genetic ${ }^{5}$ and epigenetic alterations (such as microsatellite instability), ${ }^{6}$ and a family history of colon cancer, which entail a significant risk increase ${ }^{3}$.

The time for the development of adenomatous polyps and their conversion to cancer warrants screening in the population at risk ${ }^{4,7}$. It is important to determine the prevalence of adenomas for prevention, which has been reported in the literature to range from 5.6 to $9.4 \%$, as well as the presence of polyps, which is observed in 10 to $33.7 \%{ }^{2}$. In recent years, dentate (serrated) adenomatous polyps have also been described, which histologically are hyperplastic, sessile and serrate tissue, and account for 10 to $15 \%$ of malignant neoplasms due to mutations in DNA repair genes ${ }^{7,8}$.

In the National Polyp Study, a mortality reduction of $53 \%$ was estimated after diagnosis and resection of polyps by colonoscopy ${ }^{2,9}$. The treatment for all adenomas is complete resection, and current management guidelines support the use of colonoscopy ${ }^{9,10}$.

In our country, the mortality rate for this neoplasm is 2.8 per 100,000 population ${ }^{5}$, but there are few published studies analyzing the prevalence of polyps in young individuals with no hereditary history of colorectal cancer, which has been reported in figures ranging from 1.5 to $30 \%$. 10 .

\section{Objective}

The present study aims to determine the prevalence of premalignant lesions in a Mexican population diagnosed by colonoscopy in subjects younger than
55 years in a tertiary care hospital, as well as to establish the most common location and histological type, and the risk factors associated with these lesions in said population.

\section{Method}

This was a cross-sectional, retrospective, descriptive, observational study, with information obtained from colonoscopy reports and histopathology findings of biopsies obtained in the period comprised between January 2010 and December 2014 at the Department of Colon and Rectum Surgery in the endoscopy area of the Specialty Hospital of the National Medical Center Siglo XXI of the Mexican Institute of Social Security. In addition, data on the clinical history contained in medical notes of the clinical record was also obtained. Patients younger than 55 years with colonoscopic finding of premalignant lesions, which for this work were defined as polyps, were included.

The obtained data were downloaded to a collection sheet and subjected to statistical analysis using the SPSS program, v. 20. Ratios and proportions were used for central tendency measures, as well as the chi-square test for statistical significance between variables such as patient demographics and histological and anatomical characteristics of the lesions. Subsequently, the relative risk for comorbidity associated with malignant transformation was calculated.

\section{Results}

The report of 555 colonoscopies was collected, with 276 patients younger than 55 years being found (mean: 48.8 years), out of which $58 \%$ (160) were women and $42 \%$ (116) were men. In 13 cases (4.7\%), any of the malignant lesion varieties was found.

In 65 patients (23\%), normal colonoscopy was reported, and in $113(40 \%)$, lesions regarded as premalignant were found. An incomplete or unsatisfactory diagnostic workup was reported in three patients $(1.3 \%)$ (which were excluded), and in 97 patients (35\%), other diagnoses were found (Fig. 1), including tumors with 


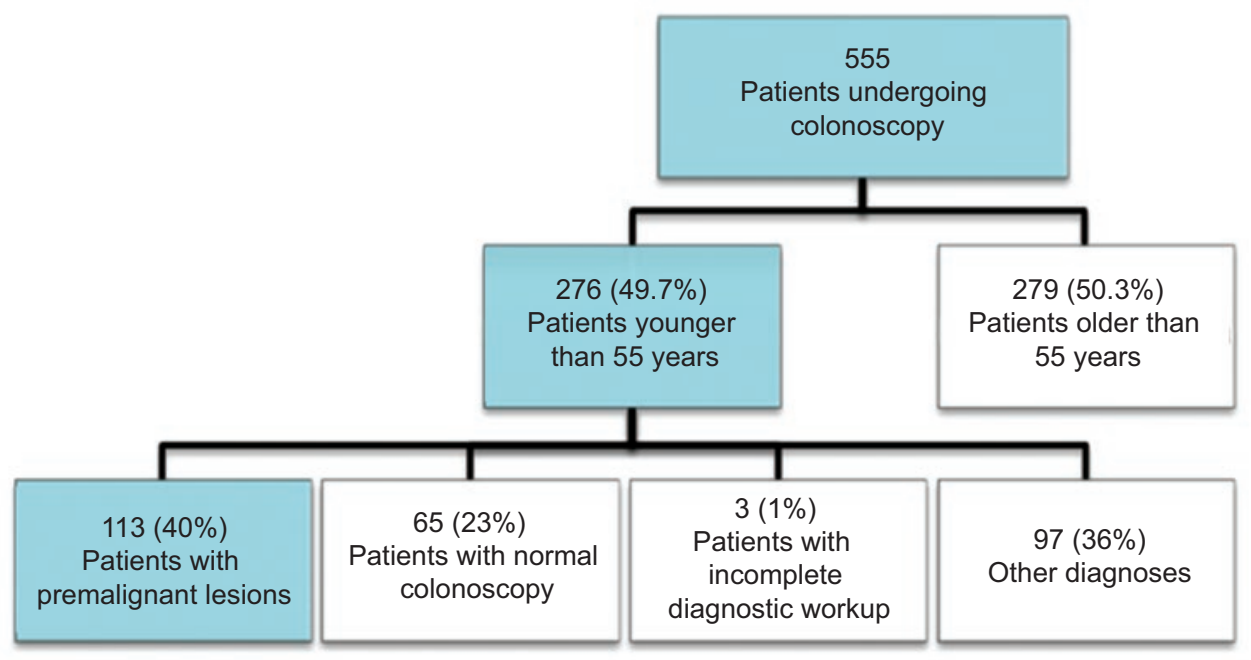

Figure 1. Distribution by age of patients undergoing colonoscopy, and findings.

malignant appearance in eight cases, which later were confirmed with histopathological report.

In 113 patients with colonoscopy findings of premalignant lesions, mean age was 44 years, $55(48 \%)$ were women and 58 (51\%) were men. Regarding patients with neoplastic and non-neoplastic lesions, more cases of lesions were observed to be found at older ages (with a higher incidence after 45 years of age).

Among the indications to perform the colonoscopy, 26 patients (23\%) who underwent screening by age group (over 50 years) were found to be asymptomatic; 16 patients (14\%) were in the study protocol due to low gastrointestinal (GI) tract hemorrhage; 9 patients $(7 \%)$ had a diagnosis of inflammatory bowel disease on follow-up; 6 patients (5\%) underwent colonoscopy as workup for unknown primary tumor or suspected primary colon neoplasm; and 3 patients $(2 \%)$ had previous diagnosis of diverticular disease.

Colonoscopy findings in these patients were the following: in $98(86 \%)$, polyps were found, out of which $53(54 \%)$ were located in the colon, $24(24.4 \%)$ in the sigmoid colon, $27(27.5 \%)$ in the rectum and one $(1 \%)$ in the anus. In seven cases, proximal and distal lesions were reported during the same study. Average size of these lesions was $5.2 \mathrm{~mm}$ (standard deviation [SD]: \pm 3.8 ).

In the histopathological report of the polyps there were 37 patients with tubular adenoma (two with highgrade dysplasia), 24 polyps were inflammatory, 18 were hyperplastic, 10 had lymphoid hyperplasia, 3 were hamartomatous, one was a serrated adenoma and one was a tubulovillous adenoma. In 13 patients, malignant lesions were found ( 9 adenocarcinomas,
2 neuroendocrine neoplasms, 1 squamous cell carcinoma and 1 colon sarcoma), and in 12 cases there was no histopathology report available (Fig. 2).

In patients in whom a premalignant lesion was described in the histopathology report (neoplastic polyps such as tubular adenoma with or without dysplasia of different degrees, tubulovillous adenoma and serrated adenoma), mean age at diagnosis was 46 years (SD: \pm 7.9$), 22$ were women $(54 \%)$ and 19 were men $(46 \%)$, with a relative risk for gender calculated at 1.4 (95\% confidence interval [Cl]: 0.8-2.2).

A history of smoking was reported in 25 patients (61\%) (with an average smoking index of 8.4, SD: \pm 5.3), and alcoholism (weekly consumption of alcoholic beverages until drunkenness) was reported in $14(34.1 \%)$. However, in the population with a history of smoking, a prevalence of neoplastic polyps of $63.2 \%$ was observed, in comparison with $36.8 \%$ in those without this history, with a calculated relative risk of 2.3 (95\% Cl: 1.5-3.7).

In patients in whom neoplastic polyps were found, personal history data of comorbidities available in the clinical record were also collected; however, no significant relationship was found with any particular pathology.

\section{Discussion}

There are few published studies on the Mexican general population analyzing the prevalence of premalignant lesions in young individuals without hereditary predisposition for colorectal cancer. In the western world, a prevalence of up to $40 \%$ of adenomatous polyps has been reported ${ }^{11}$ and, in Mexico, it is reported 


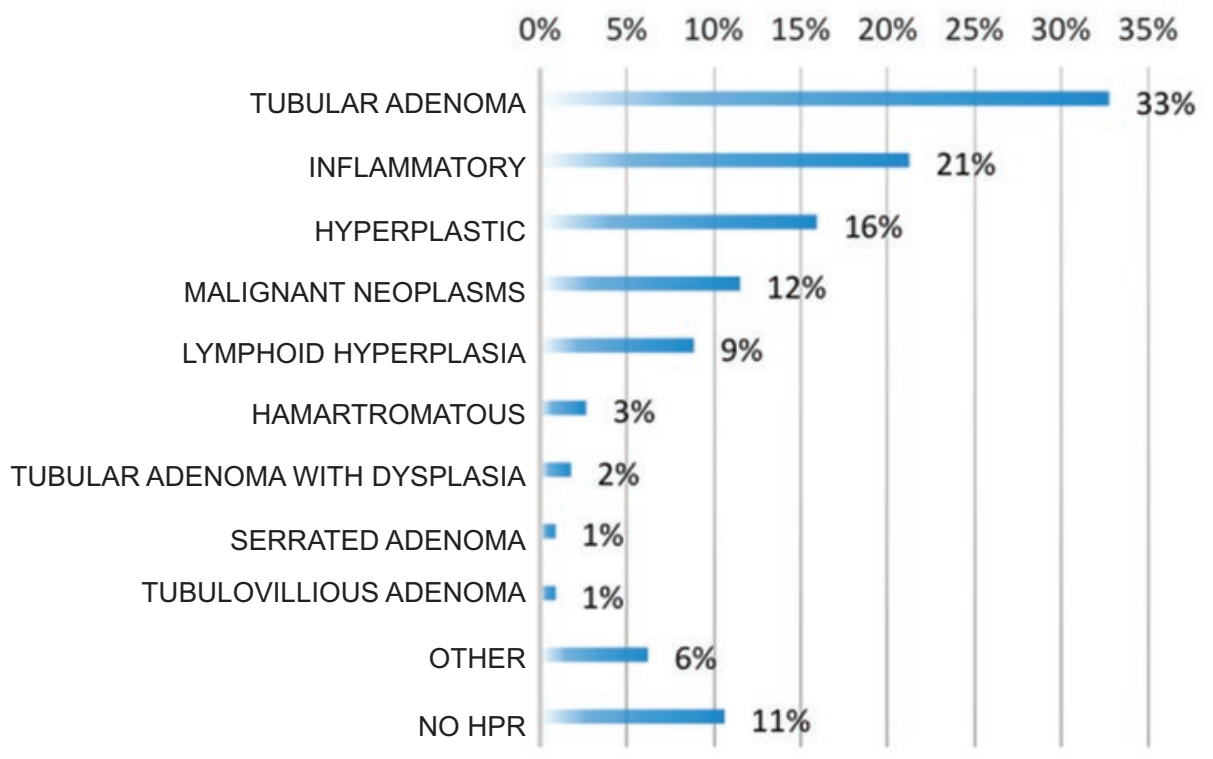

Figure 2. Frequency of histopathological types reported in resected polyps. HPR: Histopathological Report.

to range from 1.5 to $30 \%{ }^{5}$. Most screening studies in our population are carried out after 50-55 years of age, but not many studies have been published on the prevalence of lesions with malignant potential prior to this age in the Mexican population.

This work describes the findings in the population of a tertiary care hospital, where a prevalence of polypoid lesions (neoplastic and non-neoplastic) of $20 \%$, and of lesions with histopathological report of adenomas of $7.3 \%$ was found, which is consistent with the ranges reported in other previous works, which suggests that these observations could be extrapolated to the rest of the population in our country.

The most common localization in our population was the colon (right, transverse and left), in $65.9 \%$. It is important mentioning that a higher risk has been reported for proximal lesions in comparison with distal lesions, with a relative risk of 1.65 to 2.63 reported in various studies ${ }^{12}$. Regarding the size of the lesions, the mean was $5.2 \mathrm{~mm}$, which is of low risk for progression to colorectal cancer, since a statistically significant risk has been observed in lesions larger than $1 \mathrm{~cm}^{12}$, which could translate into a timely point for diagnosis and treatment prior to an increase in the risk for malignant transformation.

Regarding patients with lesions (neoplastic and non-neoplastic), a relationship was observed with age and with the number of lesions found. These findings are consistent with observations described in the international literature for age and colorectal cancer screening, ${ }^{10}$ since the prevalence of premalignant lesions increases with patient age ${ }^{12,13}$. However, the use of colonoscopy may be useful for prevention in individuals younger than 45 years with risk factors, in order to achieve a timely diagnosis of lesions with malignant potential and thus avoid an increase in the risk and progression to neoplasia. This is considered important also in patients diagnosed with hyperplastic polyps, since although historically these lesions have not been regarded as neoplastic in most classifications, some authors have recommended monitoring for their histological characteristics ${ }^{11}$, since these lesions are composed of heterogeneous tissue and have adenomatous and serrated adenoma components that increase their risk for conversion to colorectal carcinoma ${ }^{8}$.

\section{Conclusions}

In the population studied in this work, a prevalence of neoplastic and non-neoplastic lesions was found that is similar to that reported in the literature for western populations older than 50 years, which emphasizes the importance of prevention in our country, since patients who undergo polypectomy followed by colonoscopic surveillance have been reported to have a significant reduction in the incidence of colorectal cancer ${ }^{12}$.

When reviewing the results found in this population, there is a significant number of patients with reports of premalignant lesions. However, it should be noted that, in this case, prevalence is described in patients younger than 55 years, which differs from the aforementioned studies, since most include older 
patients, in whom a higher frequency of colorectal neoplasms has been described. This tells us about the important role prevention has in our country, since lesions can be identified in a timely manner, with risk reduction, and prevent their progression to malignancy.

\section{Conflicts of interest}

There are no conflicts of interest involving the authors of this study.

\section{References}

1. Hassan C, Repici A, Zullo A, Kanakadandi V, Sharma P. Colonic polyps Are we ready to resect and discard? Gast End Clinics N Am. 2013; 23:663-78.

2. Blumenstein I, Tacke W, Bock H, Filmann N, Lieber E, Zeuzem S, et al Prevalence of colorectal cancer and its precursor lesions in symptomatic and asymptomatic patients undergoing total colonoscopy: results of a large prospective, multicenter, controlled endoscopy study. Eur J Gastroenterol Hepatol. 2013;25:556-61.
3. González-González JA, Maldonado-Garza HJ, Flores-Rendon R, Garza-Galindo AA. Risk factors for colorectal polyps in a mexican population. Rev Gastroenterol Mex. 2010;2:171-6.

4. Devita VT, Lawrence TS, Rosenberg TA. Cáncer de colon. En: Cancer Principles and Practice of Oncology. 8th ed. Philadelphia: Lippincot Williams and Wilkins; 2008;1084-124.

5. Conteduca V, Sansonno D, Russi S, Dammacco F. Precancerous colorectal lesions (review). Int J Oncol. 2013;43:973-84.

6. Beggs AD, Domingo E, Abulafi M, Hodgson SV, Tomlinson IPM. A study of genomic instability in early preneoplastic colonic lesions. Oncogene. 2013;32:5333-7.

7. Mansoor S, Dolkar T, El-Fanek H. Polyps and polypoid lesions of the colon. Int J Surg Pathol. 2013;21:215-23.

8. Mi-Jung K, Eun-Jung L, Jung-Pil S, Sung-Min C, Se-Jin J, Do Sun K, et al. Traditional serrated adenoma of the colorectum. Clinicopathologic implications and endoscopic findings of the precursor lesions. Am J Clin Pathol. 2013;140:898-911.

9. Denoni C. Appropiateness of colonoscopy indication for colorectal neoplasm detection in patients under 50 years old with hematochezia. JCOL. 2012;32:40-9

10. Naini BV, Odze RD. Advanced precancerous lesions (APL) in the colonic mucosa. Best Pract Res Clin Gastroenterol. 2013;27:235-56.

11. Andreu García M, Fernández Arenas A. Pólipos colónicos y poliposis intestinal. En: Asociación Española de Gastroenterología. Manual de tratamiento de las enfermedades gastroenterológicas. 3. ${ }^{a}$ ed. Madrid: Elsevier. p. 345-57.

12. Winawer SJ, Zauber AG, Fletcher RH, Stillman JS, O'Brien MJ, Levin B, et al. Guidelines for colonoscopy surveillance after polypectomy: a consensus update by the US Multi-Society Task Force on Colorectal Cancer and the American Cancer Society. Gastroenterol. 2006;130:1872-85.

13. Steele RJC. Colorectal cancer screening. Br J Surg. 2014;101:1338-40. 